\title{
Spatial and temporal variability in juvenile bivalve dispersal: effects of sediment transport and flow regime
}

\author{
Heather L. Hunt ${ }^{1, *}$, Marie-Josée Maltais ${ }^{1}$, David C. Fugate ${ }^{2,3}{ }^{3}$, Robert J. Chant ${ }^{2}$ \\ ${ }^{1}$ Biology Department, University of New Brunswick, PO Box 5050, Saint John, New Brunswick E2L 4L5, Canada \\ ${ }^{2}$ Institute of Marine and Coastal Sciences, Rutgers University, 71 Dudley Rd., New Brunswick, New Jersey 08901-8521, USA \\ ${ }^{3}$ Present address: Department of Marine and Ecological Sciences, Florida Gulf Coast University, 10501 FGCU Blvd. South, \\ Fort Myers, Florida 33965, USA
}

\begin{abstract}
Many species of benthic marine invertebrates, including bivalves, continue to disperse as juveniles (post-settlement). This dispersal has the potential to alter patterns set up at the time of settlement. Great spatial and temporal variability in rates of dispersal of juvenile bivalves has been observed in the field. We made synoptic measurements of current speeds and rates of bedload transport of sediment and dispersal of juvenile bivalves in the Navesink estuary, New Jersey, USA to examine the contribution of spatial and temporal variation in current speed to dispersal patterns. Daily rates of juvenile bivalve dispersal were high and varied strongly across sites. Bivalve dispersal was positively related to rates of sediment transport and current velocities, but not significantly to ambient density of bivalves. Variability in bivalve dispersal across dates was considerably less than that across sites, likely because tidal current speeds varied less by date than by site. The strong relationship between bivalve dispersal and sediment transport and velocity suggests that dispersal of the bivalve species in this estuary is initiated by sediment transport.
\end{abstract}

KEY WORDS: Juvenile dispersal · Recruitment · Bivalves · Sediment transport · Shear velocity

\section{INTRODUCTION}

Many species of marine invertebrates, particularly in soft bottom habitats, continue to disperse after settlement and metamorphosis (e.g. Armonies 1992, Commito et al. 1995b, Cummings et al. 1995, Olivier et al. 1996, Commito \& Tita 2002). This dispersal of juveniles may contribute to patterns of spatial and temporal variability in recruitment. Juvenile dispersal is often important in recolonization after disturbance (e.g. Thrush et al. 1996, Hewitt et al. 2003, Zajac \& Whitlatch 2003), and for bivalves it has been suggested to result in rapid turnover of individuals (e.g. Norkko et al. 2001) and changes in spatial distribution with age (e.g. Bouma et al. 2001). Juvenile dispersal may allow individuals to migrate between nursery and adult habitats that differ in predation rates or food availabil- ity (e.g. Macoma balthica; Beukema \& de Vlas 1989, Hiddink 2003).

Dispersal of juvenile macrofauna in soft bottom habitats can be influenced by both physical factors (e.g. current speed, sediment transport) and behaviour. Juvenile invertebrates, including bivalves, often live close to the sediment surface where they are likely to be eroded by currents and waves. A number of taxa have behaviours that actively promote resuspension of juveniles and prolong drifting in the water column (e.g. byssal thread drifting of bivalves; Sigurdsson et al. 1976, Cummings et al. 1993). Other species appear to be transported more frequently along the bottom as bedload (e.g. Commito et al. 1995b, Hunt \& Mullineaux 2002). Burrowing and emergence behaviour can promote or reduce erosion of bivalves (Roegner et al. 1995, Lundquist et al. 2004). Once transport is initi- 
ated, dispersal is under the control of tidal or winddriven currents and waves.

Field observations indicate a great deal of spatial and temporal variability in rates of juvenile bivalve transport (e.g. Emerson \& Grant 1991, Commito et al. 1995a,b, Turner et al. 1997, Hunt \& Mullineaux 2002, Lundquist et al. 2006). On intertidal flats, there are positive relationships between wind conditions and flux of sediment and bivalves in sediment traps (Emerson \& Grant 1991, Commito et al. 1995b, Armonies 1996, Turner et al. 1997). Lundquist et al. (2006) found that the number of macrofaunal colonists (including bivalves) collected in traps was significantly related to physical variables associated with wind-wave activity and sediment resuspension. Juvenile bivalve transport also varies with tidal conditions (Olivier et al. 1996, Hunt \& Mullineaux 2002). Laboratory studies of juvenile bivalves indicate that dispersal rate often increases with increasing velocity (Mya arenaria: Roegner et al. 1995, Dunn et al. 1999, Gulmann et al. 2001, Hunt 2004; Austrovenus stutchburyi and Macomona liliana: Lundquist et al. 2004). Most field studies of juvenile bivalve dispersal have not collected detailed hydrodynamic data for comparison with dispersal rates (but see Lundquist et al. 2006). In this study, we made synoptic measurements of rates of transport of juvenile bivalves and sediment and of current speeds and shear velocities in an estuary. This allowed us to examine in detail the relationship between physical factors (velocity, tidal stage, sediment transport) and juvenile bivalve transport at 4 sites along a gradient in terms of current speed, sediment characteristics, and biological community on several dates with varying tidal conditions. We address the following questions: (1) Are spatial and temporal variabilities in juvenile dispersal generated more by variation in velocity due to spring/neap and ebb/flood cycles or by variation in the supply of juveniles? (2) Is juvenile bivalve transport strongly linked to sediment transport?

\section{MATERIALS AND METHODS}

This study is a component of a project (Hunt 2005 and authors' unpubl. data) examining the magnitude and scale of transport of juvenile bivalves in the Navesink River estuary. The Navesink River is located immediately south of Sandy Hook, New Jersey, USA. The Navesink estuary is approximately $10 \mathrm{~km}$ long and generally $<2 \mathrm{~m}$ deep at mean low water (MLW), with a center channel up to $5 \mathrm{~m}$ deep. The tide is semidiurnal with a range of $1.4 \mathrm{~m}$. The Navesink estuary is floodtide dominated and has strong horizontal gradients in physical characteristics (Chant \& Stoner 2001, Fugate \& Chant 2005). During the field work for the present study (June 2002 and June 2003), mean water temperatures ranged from 18 to $28^{\circ} \mathrm{C}$ and 15 to $24^{\circ} \mathrm{C}$, respectively, and salinities ranged from 20 to 25 and 12 to 23, respectively. Freshwater discharge measurements of the Swimming River, which is anthropogenically controlled and flows into the Navesink River, show that June 2003 was one of the wettest Junes in recent history (USGS data presented in Fugate \& Chant 2005).

Fieldwork was carried out at 4 subtidal sites (Fig. 1, depth at MLW 1.2 to $3.3 \mathrm{~m}$ ) spanning a gradient of sediment grain sizes and flow speeds (Table 1). Sediment grain size was estimated from small cores $(2002,2004$ : $6.35 \mathrm{~cm}$ diameter, $2 \mathrm{~cm}$ depth; 2003: $2 \mathrm{~cm}$ diameter, $8 \mathrm{~cm}$ depth) collected at each site, which were frozen and later analyzed with standard dry-sieving techniques (Folk 1965). Sediment organic content was determined from the change in weight of sediment ashed at $435^{\circ} \mathrm{C}$ for $18 \mathrm{~h}$ (Thomas 1974). Sediment samples were collected in June 2002, June 2003 (Sites 1 and 3 only), and July 2004.

Current meters were deployed at the 4 study sites on sawhorse-style mooring structures $1 \mathrm{~m}$ high, from June 14 to July 2, 2002 and June 2 to 26, 2003. All current meters were deployed in a downward-looking configuration so that measurements were as close to the bottom as possible. Measurements were made with several different types of acoustic current meters, including profilers (Sontek Acoustic Doppler Profilers [ADP] and RD Instruments [RDI] $1200 \mathrm{kHz}$ Workhorse Acoustic Doppler Current Profilers [ADCP]), which measure currents at many regular depth intervals (or cells), and single-point current meters (Nortek Aquadopp and Sontek Acoustic Doppler Velocimeters [ADVs]). The ADVs measure at high frequency in a small sample

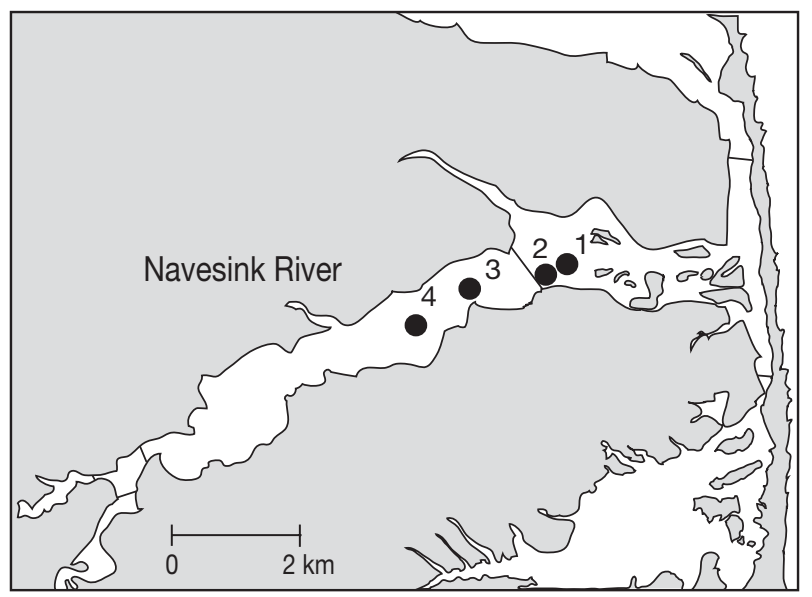

Fig. 1. Location of study sites in the Navesink River estuary, New Jersey. 1: $40^{\circ} 22.91^{\prime} \mathrm{N}, 74^{\circ} 00.48^{\prime} \mathrm{W} ; 2: 40^{\circ} 22.83^{\prime} \mathrm{N}$, $74^{\circ} 00.63^{\prime} \mathrm{W}_{i} 3: 40^{\circ} 22.74^{\prime} \mathrm{N}, 74^{\circ} 01.37^{\prime} \mathrm{W}_{i} 4: 40^{\circ} 22.45^{\prime} \mathrm{N}$, $74^{\circ} 01.99^{\prime}$ W. From Fig. 1, Hunt (2005) 
Table 1. Sediment characteristics of 4 Navesink estuary sites. Data are averages $( \pm$ SD) of samples collected in July 2002 , June 2003 (Sites 1 and 3: grain size only), and July 2004. MLW: mean low water

\begin{tabular}{|lcccc|}
\hline Site & $\begin{array}{c}\text { Depth } \\
\text { MLW }(\mathrm{m})\end{array}$ & $\begin{array}{c}\text { Mean grain } \\
\text { size }(\mu \mathrm{m})\end{array}$ & \% silt/clay & $\begin{array}{c}\% \text { organic } \\
\text { content }\end{array}$ \\
\hline 1 & 3.3 & $455 \pm 66$ & $0.12 \pm 0.16$ & $0.45 \pm 0.12$ \\
2 & 1.2 & $182 \pm 30$ & $1.31 \pm 1.12$ & $1.54 \pm 0.94$ \\
3 & 3.3 & $427 \pm 18$ & $0.40 \pm 0.42$ & $0.80 \pm 0.40$ \\
4 & 2.9 & $123 \pm 31$ & $21.8 \pm 13.7$ & $7.05 \pm 6.53$ \\
\hline
\end{tabular}

volume, enabling measurements of turbulent shear. To minimize the size of the depth cells of the profilers and maximize information near the bottom, the Sontek ADPs operated in pulse-coherent mode and the RDI ADCPs operated in mode 11, collecting single-ping data. In 2002, Sontek ADPs were deployed at Sites 1 and 4 and collected data with $3 \mathrm{~cm}$ depth cells, averaged every $15 \mathrm{~s}$. An Aquadopp was deployed at Site 2, which collected data with 30 s averages. At Site 3, 2 Sontek ADVs measured horizontal and vertical velocities for $10 \mathrm{~min}$ bursts every $30 \mathrm{~min}$ at 15 and $30 \mathrm{~cm}$ off the bottom. In 2003, Sites 1 and 3 had RDI ADCPs collecting data with $2 \mathrm{~cm}$ depth bins at a sampling frequency of $1.33 \mathrm{~Hz}$ for $10 \mathrm{~min}$ bursts every $20 \mathrm{~min}$. Mooring $2 \mathrm{had}$ a Sontek ADP, which sampled every $15 \mathrm{~s}$. Mooring 4 included 2 Sontek ADVs mounted at 0.8 and $0.5 \mathrm{~m}$ above bottom. The ADVs sampled at $10 \mathrm{~Hz}$ for 10 min bursts every $20 \mathrm{~min}$. Temperature and salinity were measured with Seabird CT sensors on the moorings.

Current meter data are presented as free stream current speeds $(u) 50 \mathrm{~cm}$ above the bottom and as estimates of shear velocity $\left(u_{*}\right)$. Shear velocity (or friction velocity) indicates the amount of friction due to turbulent shear and is the square root of the Reynolds shear stress (Vogel 1994). Erosion of particles from the bottom is generally strongly related to shear velocity (Miller et al. 1977). For the high-resolution ADCP and ADV data, shear velocities were calculated from estimates of Reynolds stress, which is the covariance of horizontal and vertical velocity deviations from the mean flow (see Fugate \& Chant 2005 for methods). The Reynolds stresses obtained from the ADCP at Site 1 in 2003 were used to estimate a drag coefficient from the current speed. This drag coefficient (0.0019) was used to estimate shear velocities from current speeds at the sites where the instruments sampled at a lower frequency (Aquadopp and ADP data) using the equation:

$$
u_{*}=\sqrt{C} \times u
$$

where $C$ is the drag coefficient, $u_{*}$ is the shear velocity, and $u$ is the current speed. We did not use the common technique of estimating shear velocity from the slope of the relationship between height above the bottom and velocity in a logarithmic boundary layer ('law of the wall', Vogel 1994) because Fugate and Chant (2005) showed that log profile estimates of shear stress were poorly related to Reynolds stress estimates in the Navesink estuary in 2003, due to inhibition of turbulence by upper layer pycnoclines.

A $6 \mathrm{~m}$ transect was set up perpendicular to the current at each site. Because poor visibility limited the SCUBA divers' ability to relocate objects, traps and pans (described below) were positioned $0.5 \mathrm{~m}$ away from each transect, on opposite sides, at $1 \mathrm{~m}$ intervals.

Results of previous studies suggest that dispersal of Gemma gemma and Mya arenaria, which were expected to be common in the Navesink estuary, is generally linked to bedload transport (Emerson \& Grant 1991, Commito et al. 1995a, Hunt \& Mullineaux 2002). Cylindrical traps were installed flush with the sediment surface to measure the flux of clams and sediment transported as bedload or falling out of suspension in the water column. These bedload traps were similar to those used in a number of previous studies (Emerson 1991, Commito et al. 1995b, Turner et al. 1997, Hunt \& Mullineaux 2002). The traps were cut from PVC pipe (outer diameter $4.8 \mathrm{~cm}$, inner diameter $3.6 \mathrm{~cm}$, depth $42 \mathrm{~cm}$ ) with an aspect ratio of 11.7:1. The bottom of each trap was sealed with a rubber stopper, and a piece of galvanized metal mesh $(4 \mathrm{~mm})$ was placed inside each trap $10 \mathrm{~cm}$ from the bottom to prevent any crabs that entered the traps from preying on clams accumulated on the bottom. Each trap was held inside an outer sleeve (outer diameter $6.0 \mathrm{~cm}$, inner diameter $5.2 \mathrm{~cm}$, depth $45 \mathrm{~cm}$ ) by an O-ring in a groove machined on the outer surface of the trap. The outer sleeve allowed for easy deployment and removal of the trap without disturbing the surrounding sediment. Five outer sleeves were installed at each of the 4 sites 6 to $12 \mathrm{~d}$ before the traps were first deployed in 2003 and 2002, respectively. At the start of each trap deployment, the sleeves were uncapped, and a trap filled with filtered seawater was placed inside each sleeve. The traps were deployed for $24 \mathrm{~h}$ intervals beginning June 19 and 27, 2002 and June 4 and 16, 2003. To compare ebb and flood tide at Sites 1 and 3, traps were deployed at 2 sequential slack tides ( 5 to $6 \mathrm{~h}$ intervals) on both June 11 and 18, 2003.

To measure the net transport of bivalves (balance of immigration and emigration), we deployed pans (diameter $14.2 \mathrm{~cm}$ ) filled with sediment and buried flush with the sediment surface (Turner et al. 1997). The pans (total depth $5.5 \mathrm{~cm}$ ) contained a layer of dental stone coated with silicone on top of which we added a $1.5 \mathrm{~cm}$ layer of sediment from the sites above. Sediment for the pans was collected at each study site in late May 2002 and 2003 when densities of juvenile clams were low. The sediment was sieved through a 
$1 \mathrm{~mm}$ mesh sieve to remove shell fragments and macrofauna and held in a recirculating seawater system until it was placed in the pans $1 \mathrm{~d}$ before deployment. At each site, 5 pans were deployed for the same $24 \mathrm{~h}$ intervals as the traps. The sediment was not frozen, so that a natural bacterial assemblage would be present to act as a colonization cue. However, samples of sediment used in the pans indicated that some live clams were present, and may have resulted in overestimates of bivalve transport into pans. We estimate that 3 to 14 (density 190 to 900 ind. $\mathrm{m}^{-2}$ ) juvenile bivalves may have been present in the pans upon deployment in 2002 and 0 to 5 (density 0 to 300 ind. $\mathrm{m}^{-2}$ ) bivalves per pan in 2003. This artefact is estimated to represent $<10 \%$ of the bivalves collected per pan at Sites 1, 3, and 4 in 2002 but may account for much of the bivalve density in pans at Site 2 in 2002 and at all sites in 2003 when dispersal of bivalves into pans was low. As a result, pan data for 2003 and for Site 2 in 2002 were not included in statistical analyses.

The ambient density of juvenile bivalves at the study sites was estimated from the density in small cores (diameter $6.35 \mathrm{~cm}$, depth $2 \mathrm{~cm}$ ). Five cores were collected from each site on the dates when traps and pans were collected, with a few exceptions. For the $24 \mathrm{~h}$ samples at Sites 2 and 3 in 2002, data from cores collected for a transplant experiment $1 \mathrm{~d}$ prior to the trap and pan deployment (June 18 and 26) were used. For ebb/flood samples on June 11, 2003, cores collected the previous day during a transplant experiment (authors' unpubl. data) were used for Site 3. For the ebb/flood samples on June 18, cores collected the previous day for the $24 \mathrm{~h}$ trap and pan deployment were used for the comparisons with trap samples at both sites. At all 4 sites, large cores (diameter $12 \mathrm{~cm}$, depth $17 \mathrm{~cm} ; 5$ cores per site) were collected on June 17, 2003 to assess the abundance of larger, deeper-burrowing juvenile and adult bivalves $>2 \mathrm{~mm}$ shell length (SL), which were not sampled well by the $2 \mathrm{~cm}$ deep cores.

The contents of the traps, pans and small cores were sieved on a $180 \mu \mathrm{m}$ sieve, while the large cores were sieved on a $2 \mathrm{~mm}$ sieve. All samples were preserved in $80 \%$ ethanol and stained with rose bengal for later sorting and enumeration. Before sorting, samples were sieved through nested 500 and $180 \mu \mathrm{m}$ sieves. Animals in the 180 to $500 \mu \mathrm{m}$ fractions were separated from most of the sediment by swirling the sample in water and decanting the lighter supernatant fraction containing the animals. Both the 500 and $180 \mu \mathrm{m}$ fractions were examined under a binocular microscope and all bivalves were counted. Shell lengths were measured using an ocular micrometer for all bivalves in 2 to 3 replicates for traps, pans, and cores collected on June 28, 2002 (see analysis of size distributions). The total dry weight of material (sediment, tube mats, shell hash, algae)
$>180 \mu \mathrm{m}$ in the traps was measured after the macrofauna was removed.

Although 5 samples were collected per site per date for traps, pans, and cores, some samples were lost or had to be excluded because particular traps or pans were not flush with the substratum. As a result, replicates in the analyses varied from 2 to 5 per site and date combination (particularly for traps). If necessary (as determined by Cochran's test with $\alpha=0.05$ ), weights and densities were $\ln (x+1)$ transformed, and proportions were arcsin $\sqrt{x}$ transformed prior to analysis to satisfy the assumption of homogeneity of variances.

The proportion of bivalves $<500 \mu \mathrm{m}$ (passing through a $500 \mu \mathrm{m}$ sieve) was compared among sites (1 and 3 in 2002 and 1, 2, and 3 in 2003) and sampling methods (traps, pans [2002 only], and cores) using 2way ANOVA. Not all sites were included in this analysis since few samples from these sites contained bivalves (0 to 3 samples per site, with the exception of cores at Site 2 in 2002), which prevented calculation of proportions of bivalves $<500 \mu \mathrm{m}$ for enough samples for statistical comparison. To examine sizes of dispersing bivalves more closely, size distributions of Gemma gemma (pooled from several of the replicates for each sampling method) on June 28, 2002 were compared between sites (1 and 3) and sampling methods (traps, pans, cores) using Kolmogorov-Smirnoff tests. $G$. gemma individuals were grouped into $100 \mu \mathrm{m}$ size classes. Size distributions of 347 (Site 1) and 246 (Site 3) G. gemma individuals from traps, 109 and 94 from pans, and 54 and 51 individuals from cores from Sites 1 and 3 respectively were used. Size distributions of other species of bivalves and other sampling dates were not examined because of low sample sizes.

For the $24 \mathrm{~h}$ samples, variation among sites and dates in the transport rate of bivalves in the traps and pans, and the density of bivalves in the cores were examined using 2-way ANOVA. Both site and date were fixed factors. The years 2002 and 2003 were analyzed separately because the abundance of bivalves was an order of magnitude lower in 2003. In addition, no usable data were obtained for the Site 1 traps on the first sampling date in 2002, so there were only 3 sites in the trap analyses for 2002. For the ebb and flood samples collected from Sites 1 and 3 in 2003, sediment weight in traps was examined in a 3-way ANOVA with site (Sites 1 and 3), Date, and Tidal stage (ebb, flood) as factors. Densities of bivalves in the ebb/flood samples were very low because they were collected over $6 \mathrm{~h}$ intervals. Because only 1 bivalve was collected from traps at Site 3 during the ebb and flood samples, bivalve dispersal was analyzed for Site 1 only in a 2way ANOVA with Date and Tidal stage (ebb, flood) as fixed factors. 
The relationship between the transport rate of bivalves into traps and the density of bivalves in cores and weight of sediment in traps was examined by multiple regression for 2002 and 2003. A similar analysis was done for the transport rate of bivalves into pans in 2002. Regression was also used to examine the relationship between bivalve transport into traps and velocity (current speed at $50 \mathrm{~cm}$ above bottom, or shear velocity), and between the weight of sediment in traps and velocity. For all regressions, the data points were averages for each site on a particular date. For current velocity, means of absolute values of velocity were used, since flood values were presented as negative numbers and ebb values as positive. Data for 2002 and 2003 were analyzed separately. As a result, $\mathrm{n}=7$ (in 2002, no data for traps at Site 1 on June 20 ) or 8 (in 2003, 4 sites $\times 2$ dates).

\section{RESULTS}

\section{Physical characteristics}

In 2002, maximum current speeds above bottom were $90 \mathrm{~cm} \mathrm{~s}^{-1}$ at Site 1, with lower current speeds at the other sites: 42,28 , and $16 \mathrm{~cm} \mathrm{~s}^{-1}$ at Sites 2, 3, and 4 (Fig. 2). In 2003, maximum current speeds recorded by the moorings were $67 \mathrm{~cm} \mathrm{~s}^{-1}$ at Site 1 and 19, 28, and $26 \mathrm{~cm} \mathrm{~s}^{-1}$ at Sites 2, 3, and 4, respectively (Fig. 3). At all sites, flood tides were stronger than ebb tides. Shear velocity was estimated from the current meter data. Maximum shear velocities were greatest at Sites 1 and 3, where they were 2 (2002) to 4 (2003) times higher than at Site 2, and 4 (2003) to 5 (2002) times higher than at Site 4 (Fig. $2 \& 3$ ). Shear velocities at Sites 1 and 3 were more similar than along-channel current speeds at $50 \mathrm{~cm}$ above bottom. This is likely due to the topography at Site 3, which resulted in significant cross channel velocities not shown in Figs. 2a \& 3a, but accounted for in the shear velocity estimates in Figs. $2 b$ $\& 3 \mathrm{~b}$. Shear velocity at Site 3 was noisy because of the topography as this site is located at the end of a sand bar, which causes a constriction in the estuary.

In 2002, the $24 \mathrm{~h}$ measurements were made on June 19-20 and June 27-28. Velocities were similar on both occasions (Fig. 2, Table 2), with no strong spring or neap tides. In 2003, the $24 \mathrm{~h}$ measurements were made on June 4 and 5, a neap tide, and June 16 and 17, a spring tide. Mean current speed at $50 \mathrm{~cm}$ above bottom and shear velocity were greater on June 16 and 17 than June 4 and 5 at Site 1 only (Table 2). Trap samples were collected during ebb and flood tides on June 11 and 18, 2003. As in the longer record, flood tides were stronger than ebb currents on these dates (Fig. 3, Table 2). Mean velocities were greater on June 11 than June 18 (Table 2).
The sediments from Sites 1 and 3 were coarse sand (mean grain sizes 455 and $427 \mu \mathrm{m}$, respectively) while those from Sites 2 and 4 were considerably finer (182 and $123 \mu \mathrm{m}$, respectively) (Table 1). The silt/clay content $(<63 \mu \mathrm{m})$ of the sediment was $<2 \%$ at Sites 1, 2, and 3, but $21.8 \%$ at Site 4 . Sediment organic content ranged from $0.5 \%$ at Site 1 to $7.1 \%$ at Site 4 (Table 1).

\section{Species composition and size of juveniles}

In 2002, $>75 \%$ of bivalves collected at Sites 1 and 3 were Gemma gemma (recent settlers and adults) (Table 3). In 2003, the percentage of G. gemma at Site 1 was again $>75 \%$ of the total, while that at Site 3 was somewhat lower (Table 3). G. gemma individuals were less abundant at Sites 2 and 4, which had finer sediment. A variety of other bivalves were found at the 4 sites, including juveniles of Lyonsia hyalina, Tellina agilis, Mya arenaria and Mercenaria mercenaria (Table 3). The bivalves collected in traps and pans were generally small. The largest individuals collected in traps and pans were juvenile Mercenaria mercenaria (max. $11.3 \mathrm{~mm}$ ) and T. agilis (max. $11.9 \mathrm{~mm}$ ). In 2002, the majority of juvenile bivalves in the traps and cores were recent settlers, passing through a $500 \mu \mathrm{m}$ sieve (Table 3). Statistical tests comparing proportions of bivalves $<500 \mu \mathrm{m}$ could be carried out for Sites 1 (June 28, only for traps) and 3 only, because few trap and pan samples from Sites 2 and 4 contained bivalves. On June 20, the proportion of bivalves $<500 \mu \mathrm{m}$ was significantly less at Site 3

Table 2. Mean along-channel velocities $50 \mathrm{~cm}$ above bottom $\left(u, \mathrm{~cm} \mathrm{~s}^{-1}\right)$ and shear velocities $\left(u *, \mathrm{~cm} \mathrm{~s}^{-1}\right)$ at the 4 study sites during trap and pan deployment. Means are of absolute values of velocities since flood tides were recorded as negative values and ebb currents as positive. Fld = flood

\begin{tabular}{|c|c|c|c|c|c|c|}
\hline \multirow[t]{2}{*}{ Site } & \multicolumn{2}{|c|}{$-2002-$} & \multirow[b]{2}{*}{ Jun 4} & \multirow{2}{*}{\multicolumn{2}{|c|}{$\begin{array}{ll} & 2003 \\
\text { Jun } 16 & \text { Jun } 11\end{array}$}} & \multirow[b]{2}{*}{ Jun 18} \\
\hline & Jun 19 & Jun 27 & & & & \\
\hline \multicolumn{7}{|l|}{$\boldsymbol{u}$} \\
\hline 1 & 34.7 & 35.9 & 20.3 & 29.0 & \multirow[t]{2}{*}{$\begin{array}{c}\text { Ebb } 29.0 \\
\text { Fld } 41.2\end{array}$} & \multirow[t]{2}{*}{$\begin{array}{l}\text { Fld } 31.5 \\
\text { Ebb } 20.6\end{array}$} \\
\hline 2 & 16.1 & 15.6 & 7.0 & 4.5 & & \\
\hline 3 & 8.5 & 9.6 & 7.4 & 9.4 & \multirow[t]{2}{*}{$\begin{array}{l}\text { Ebb } 1.9 \\
\text { Fld } 19.7\end{array}$} & \multirow[t]{2}{*}{$\begin{array}{l}\text { Fld } 14.2 \\
\text { Ebb } 1.9\end{array}$} \\
\hline 4 & 4.8 & 6.3 & 10.0 & 12.4 & & \\
\hline \multicolumn{7}{|l|}{$\boldsymbol{u}_{*}$} \\
\hline 1 & 1.51 & 1.57 & 0.90 & 1.34 & \multirow[t]{2}{*}{$\begin{array}{l}\text { Ebb } 1.00 \\
\text { Fld } 2.02\end{array}$} & \multirow[t]{2}{*}{$\begin{array}{l}\text { Fld } 1.61 \\
\text { Ebb } 0.87\end{array}$} \\
\hline 2 & 0.73 & 0.71 & 0.39 & 0.30 & & \\
\hline 3 & 0.69 & 0.77 & 0.97 & 0.96 & \multirow[t]{2}{*}{$\begin{array}{l}\text { Ebb } 0.67 \\
\text { Fld } 1.41\end{array}$} & \multirow[t]{2}{*}{$\begin{array}{l}\text { Fld } 1.23 \\
\text { Ebb } 0.80\end{array}$} \\
\hline 4 & 0.26 & 0.29 & 0.29 & 0.20 & & \\
\hline
\end{tabular}



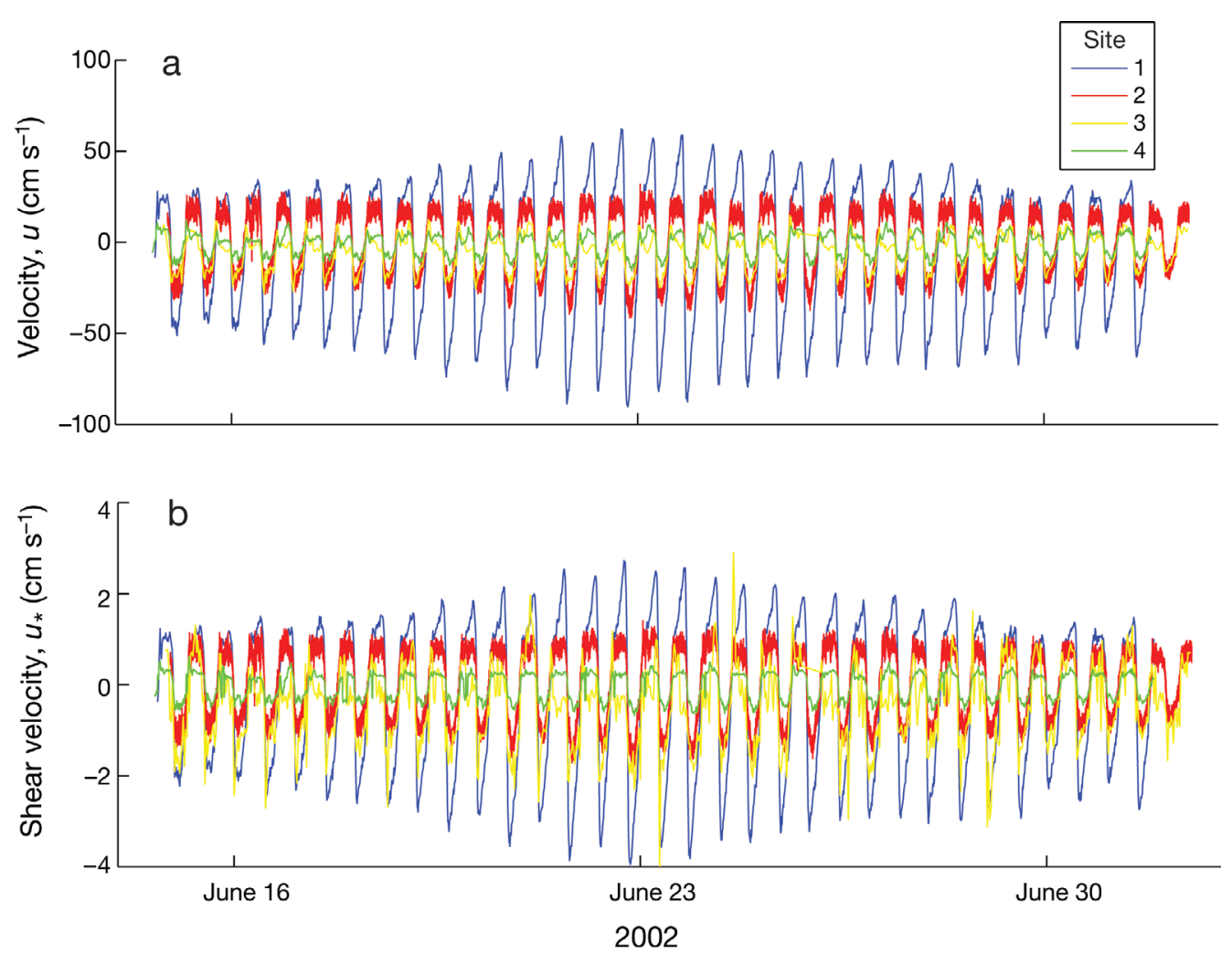

Fig. 2. Time series of along-channel (a) current speeds ( $u, 50 \mathrm{~cm}$ above bottom) and (b) shear velocity $\left(u_{*}\right)$ from Reynolds or quadratic stresses at the 4 Navesink estuary study sites from June 14 to July 2, 2002 (flood values are negative)
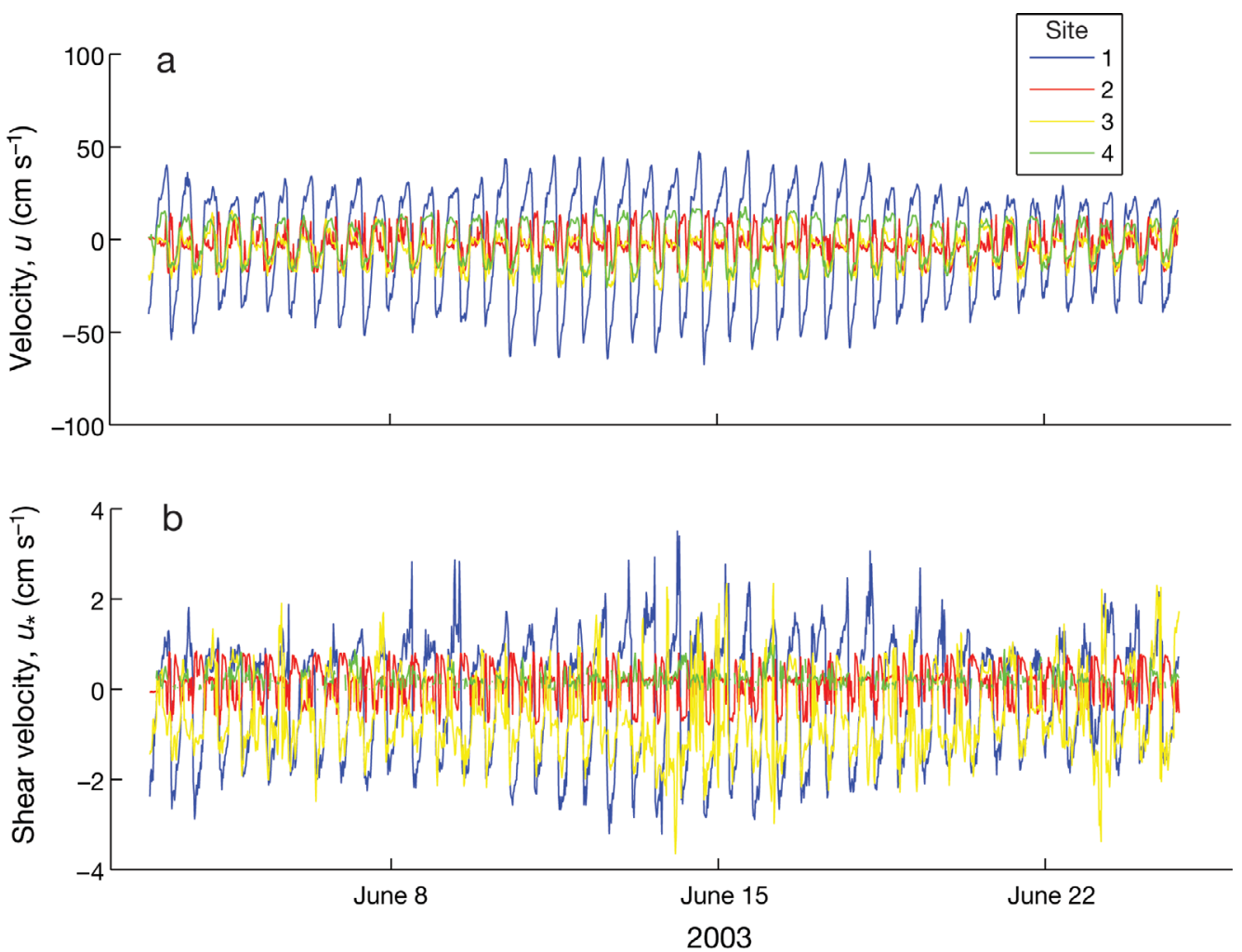

Fig. 3. Time series of near-bottom (a) current speeds $\left(u_{1}, 50 \mathrm{~cm}\right.$ above bottom) and (b) shear velocity $\left(u_{*}\right)$ from Reynolds or quadratic stresses at the 4 Navesink estuary study sites from June 2 to 26, 2003 (flood values are negative) 
Table 3. Mean $( \pm \mathrm{SE}$, in parentheses) percentage of recent settlers (bivalves passing through a $500 \mu \mathrm{m}$ sieve) and species composition of juvenile bivalves in traps, pans, and small cores for the $24 \mathrm{~h}$ sampling intervals in 2002 and 2003 (n = 2 to 5 replicates; means based only on replicates containing bivalves). - = sites/dates for which no bivalves were collected in any of the replicates,

$$
\mathrm{ND}=\text { no usable data }
$$

\begin{tabular}{|lcccccccl|}
\hline \multirow{2}{*}{ Date } & Site & \multicolumn{3}{c}{$\%<500 \mu \mathrm{m}$} & \multicolumn{5}{c}{$\%$ Gemma gemma } & \multirow{2}{*}{ Species other than G. gemma } \\
& & Traps & Pans & Cores & Traps & Pans & Cores & \\
\hline Jun 20, & 1 & ND & $90(4)$ & $97(1)$ & ND & $87(5)$ & $78(9)$ & Lyonsia hyalina, Tellina agilis \\
2002 & 2 & 100 & $50(50)$ & $87(8)$ & 0 & $50(71)$ & $47(12)$ & Mya arenaria, L. hyalina, T. agilis \\
& 3 & $93(4)$ & $23(11)$ & $73(18)$ & $80(20)$ & $94(6)$ & $96(2)$ & M. arenaria, T. agilis, Mercenaria mercenaria \\
& 4 & 100 & $0(0)$ & - & 0 & $75(25)$ & - & M. arenaria, T. agilis \\
Jun 28, & 1 & $87(4)$ & $61(2)$ & $80(4)$ & $97(1)$ & $99(1)$ & $95(2)$ & M. arenaria, L. hyalina, T. agilis \\
2002 & 2 & $100(0)$ & $33(33)$ & $80(12)$ & $50(50)$ & $33(33)$ & $54(17)$ & M. arenaria, L. hyalina, T. agilis \\
& 3 & $66(3)$ & $16(8)$ & $82(6)$ & $97(1)$ & $93(4)$ & $94(3)$ & M. arenaria, T. agilis, M. mercenaria \\
& 4 & 0 & 0 & 0 & 0 & 100 & 0 & T. agilis \\
Jun 5, & 1 & $0(0)$ & $0(0)$ & $0(0)$ & $100(0)$ & $100(0)$ & $97(2)$ & M. mercenaria \\
2003 & 2 & $0(0)$ & 0 & $0(0)$ & $0(0)$ & 0 & $7(7)$ & Mussels, M. mercenaria, T. agilis \\
& 3 & - & $50(50)$ & $0(0)$ & - & $100(0)$ & $50(50)$ & T. agilis \\
Jun 17, & 1 & $49(4)$ & $53(11)$ & $51(18)$ & $91(2)$ & $90(2)$ & $77(9)$ & M. arenaria, L. hyalina, M. mercenaria, T. agilis \\
2003 & 2 & $20(20)$ & $0(0)$ & $50(29)$ & $24(10)$ & $17(17)$ & $83(17)$ & M. arenaria, M. mercenaria, T. agilis, L. hyalina \\
& 3 & $80(20)$ & $56(29)$ & $33(33)$ & $70(20)$ & $56(29)$ & $33(33)$ & M. arenaria, T. agilis \\
& 4 & 0 & 0 & - & 0 & 0 & - & M. balthica \\
\hline
\end{tabular}

than at Site 1 , and significantly less in pans than in cores (Table 4). On June 28, there was a significant interaction between site and sampling method (Table 4). In general, there were significantly lower proportions of bivalves $<500 \mu \mathrm{m}$ in pans than in traps. Settlement occurred late in 2003, a record-setting rainy spring. On June 5, 2003, only one individual $<500 \mu \mathrm{m}$ was collected. On June 17, approximately half of individuals collected were $<500 \mu \mathrm{m}$ in size (Table 3 ). The percentage of bivalves $<500 \mu \mathrm{m}$ on June $17 \mathrm{did}$ not differ significantly between traps and cores or between sites (Table 4). Large numbers of Mya arenaria larvae were still present in the water column on June 25, 2003, when plankton tows were carried out to detect whether juvenile bivalves were resuspended into the water column.

For June 28, 2002, sizes of the most common bivalve Gemma gemma were examined in more detail by comparing size distributions between Sites 1 and 3 and among sampling methods. Kolmogorov-Smirnoff tests showed that size distributions differed between traps and pans, pans and cores, and traps and cores for Site 3 (max. $D=0.46,0.62,0.30$ respectively, $\mathrm{p}<$ 0.05 ) but not for Site 1 (max. $D=0.14,0.22,0.10$ respectively, $\mathrm{p}>0.05$ ). At Site 3 , cores had the largest proportion of G. gemma individuals $<400$ or $500 \mu \mathrm{m}$, while pans had the smallest. Size distributions differed significantly between Site 1 and 3 for traps, pans, and cores (max. $D=0.24,0.51$, and 0.34, respectively; p < 0.05). G. gemma individuals were significantly smaller at Site 1 than 3 in the traps and pans, but significantly larger at Site 1 than 3 in the cores.

\section{Spatial and temporal patterns}

Because species other than Gemma gemma occurred in numbers too small to be analyzed separately, all species and sizes of bivalves were pooled to

Table 4. Two-way ANOVAs for proportion of bivalves in traps, pans, and cores $<500 \mu \mathrm{m}$ SL (shell length) on June 20 and 28, 2002 and June 17, 2003. Fixed factors were Site (2002: 1 and $3 ; 2003: 1,2$ and 3) and Sampling Method (traps [except June 20, 2002], pans [except 2003], and cores). $\mathrm{n}=5$ replicates, except in cases where samples were lost, or traps or pans were improperly deployed. Post hoc comparisons $(\alpha=0.05)$ done with Tukey-Kramer HSD tests. Numerals in comparison refer to sites; Sampl Meth = sampling method

\begin{tabular}{|lrrll|}
\hline Factors & df & \multicolumn{1}{c|}{$F$} & $\mathrm{p}$ & Comparison \\
\hline Jun 20, 2002 & & & & \\
Site & 1 & 11.6 & 0.004 & $1>3$ \\
Sampl Meth & 1 & 4.6 & 0.05 & cores > pans \\
Site $\times$ Meth & 1 & 1.9 & 0.18 & \\
Residual & 14 & & & \\
Jun 28, 2002 & & & & \\
Site & 1 & 21.9 & 0.0001 & \\
Sampl Meth & 2 & 36.6 & $<0.0001$ & \\
Site $\times$ Meth & 2 & 9.0 & 0.0016 & 3: cores $=$ traps $>$ pans; \\
Residual & 20 & & & $1:$ traps $=$ cores, traps > \\
& & & & pans; traps and cores: \\
& & & & $1=3$; pans: $1>3$ \\
Jun 17, 2003 & & & & \\
Site & 2 & 0.46 & 0.64 & \\
Sampl Meth & 1 & 0.06 & 0.82 & \\
Site $\times$ Meth & 2 & 1.40 & 0.27 & \\
Residual & 18 & & & \\
\hline
\end{tabular}


examine spatial and temporal variability in bivalve transport (trap samples) and distribution (small cores). There was strong spatial variability in bivalve and sediment transport and bivalve density in both 2002 (Fig. 4) and 2003 (Fig. 5). In both years, rates of transport of bivalves into traps were highest at Site 1 and
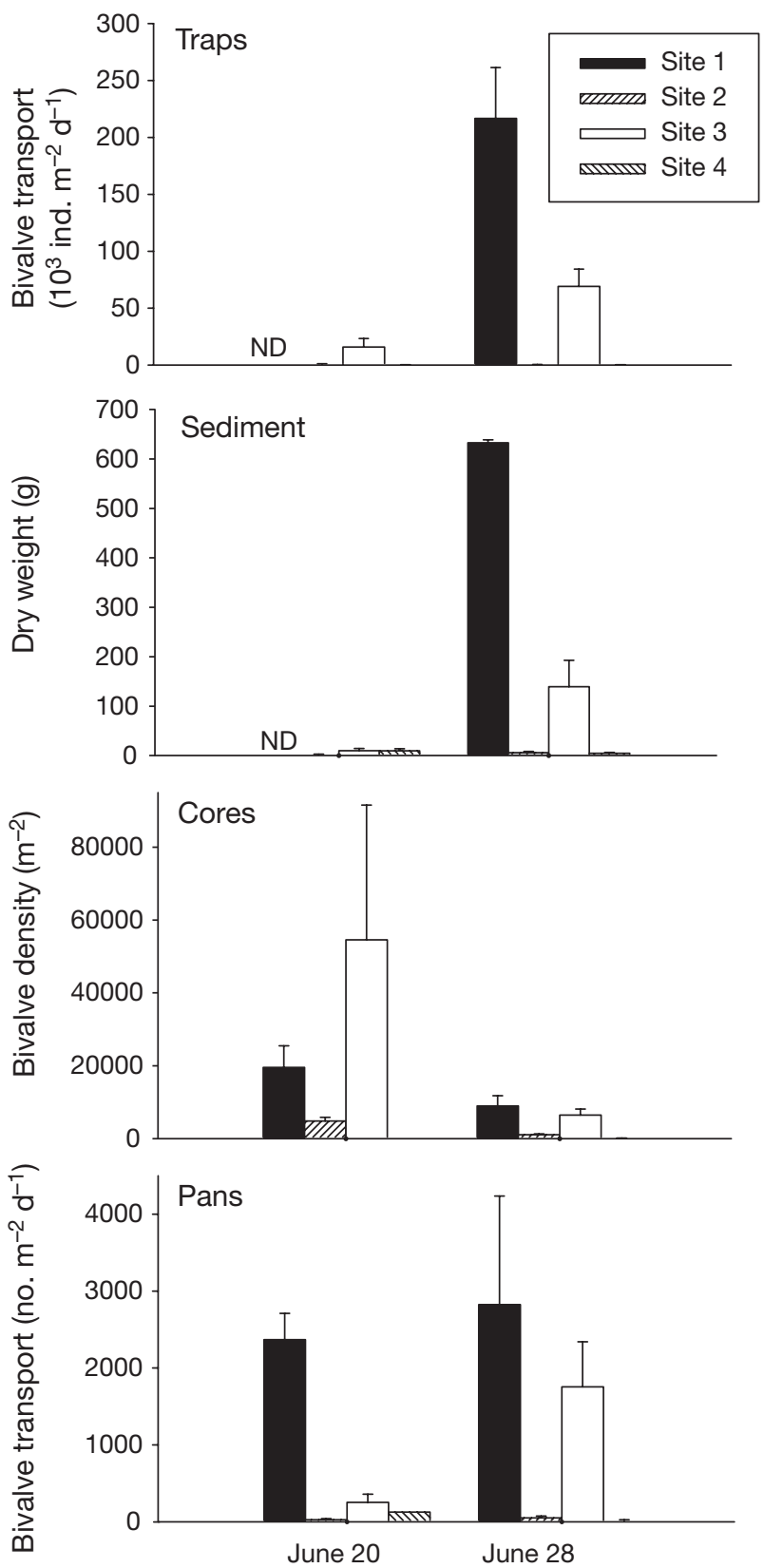

Fig. 4. Mean (+SE, $\mathrm{n}=2$ to 5 for each site) transport of bivalves into bedload traps, dry weight of sediment collected in traps, density of bivalves in the surrounding sediment, and colonization of pans by bivalves at the 4 Navesink estuary sites on June 19-20 and June 27-28, 2002. No usable data (ND) were obtained from Site 1 traps on June 20 since they were deployed projecting above the bottom lowest at Site 4. Relative rates of transport of bivalves into traps were greater at Site 3 than at Site 2 in 2002, and the reverse in 2003. In 2002, the transport rate of bivalves into traps on both dates and sediment in traps on June 20 was significantly greater at Site 3 than at Sites 2 and 4 (Site 1 not included in analysis,
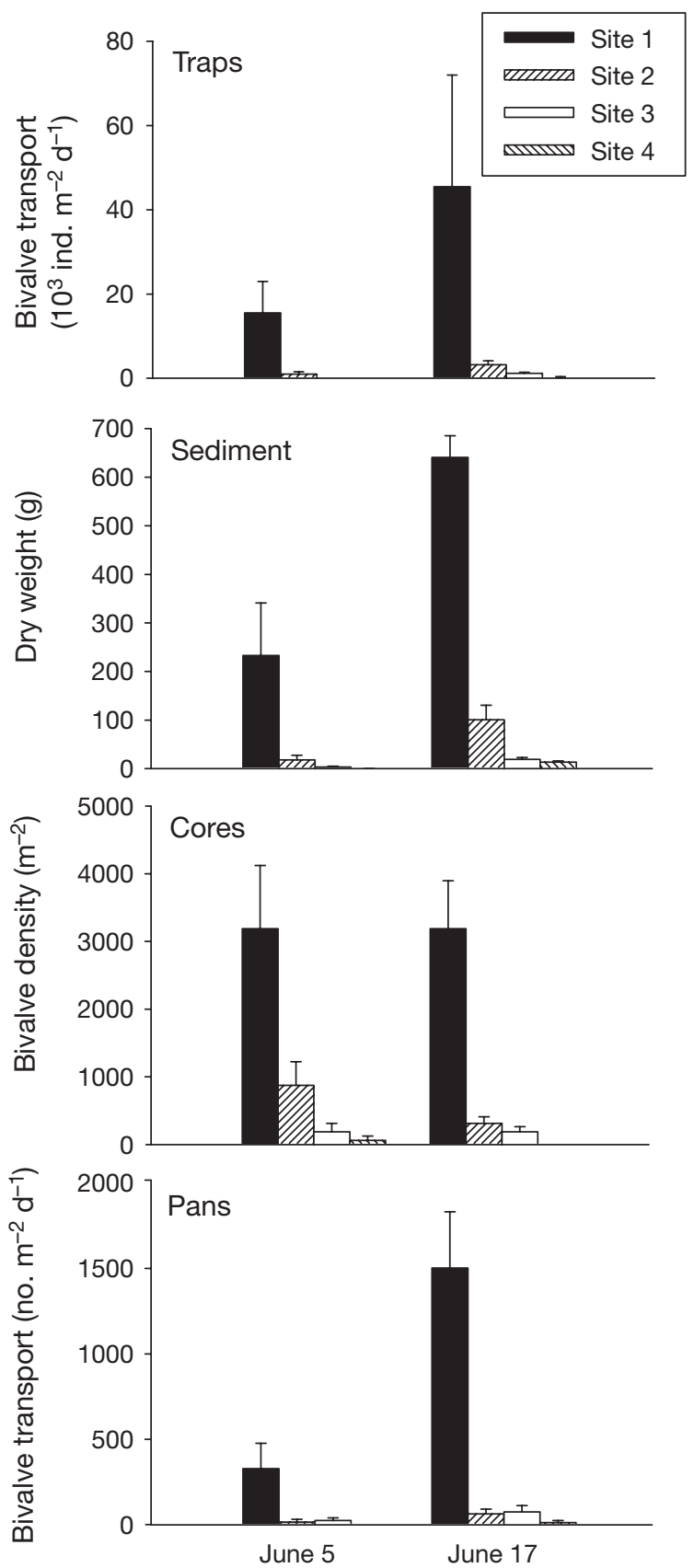

Fig. 5. Mean (+SE, $\mathrm{n}=2-5$ for each site) transport of bivalves into bedload traps, dry weight of sediment collected in traps, density of bivalves in the surrounding sediment, and colonization of pans by bivalves at the 4 Navesink estuary sites on June $4-5$ and $16-17,2003$ 
due to missing data for June 20), while the amount of sediment in traps did not differ significantly among Sites 2, 3, and 4 on June 20 (Table 5). For June 28 only, all 4 sites were compared. The transport rates of bivalves and weights of sediment in traps differed significantly among sites (bivalves: $F_{3,14}=20.1, \mathrm{p}<0.0001$; sediment: $\left.F_{3,14}=42.9, \mathrm{p}<0.0001\right)$. Rates of transport of juvenile bivalves were significantly greater at Sites 1 and 3 than at Sites 2 and 4, while total weight of sediment in the traps was significantly greater at Site 1 than at Site 3; sediment transport at both Sites 1 and 3 was significantly greater than at Sites 2 and 4 (Tukey-Kramer Honestly Significant Difference HSD, test, $\mathrm{p}<0.05)$. Rates of dispersal into traps were lower in 2003, most likely due to lower densities of bivalves in the surrounding area (Figs. 4 \& 5). In 2003, as in 2002, bivalves were most abundant in traps at Site 1 and lowest at Site 4 on both sampling dates (Table 5). A significantly greater weight of sediment was collected in traps at Sites 1 and 2 compared to Sites 3 and 4 . No significant temporal variation in rates of transport of bivalves or sediment into traps was detected in 2002 (Table 5), while in 2003, transport of bivalves into traps differed between dates only for Site 3, where significantly more bivalves were found in traps on June 17 than June 5. A significantly greater weight of sediment was collected in the traps on June 17, when current velocities were greater (Table 2), than on June 5, 2003 (Table 5).

Net transport rates of bivalves into pans were 1 to 2 orders of magnitude lower than gross rates of transport into traps. However, similar spatial patterns were detected (Figs. 4 \& 5). In 2002, there were significantly more bivalves in pans at Site 1 than at Site 4 , with no significant difference between dates (Table 5). Patterns of abundance of bivalves in cores were similar to those in pans. In 2002, there were significantly greater densities of bivalves in cores at Sites 1 and 3 than at Sites 2 and 4, and significantly greater at Site 2 than at Site 4 (Table 5). In 2003, there were greater relative densities of bivalves at Site 2 than at Site 3, the reverse of 2002 (Figs. 4 \& 5), resulting in significantly higher densities of juvenile bivalves in cores at Sites 1 and 2 than at Sites 3 and 4 (Table 5). Density in cores did not differ significantly between dates in either year (Table 5).
Table 5. Two-way ANOVA for rates of bivalve transport into traps and in 2002 and 2003. Fixed factors were Site (2002: 3 sites for traps, 4 otherand Date (2002: June 19-20, 27-28, 2003: June 4-5, 16-17). $\mathrm{n}=5$ eplicates, except in cases where samples were lost, or traps or pans were Kramer HSD tests. Numerals 1 to 4 in comparison refer to sites

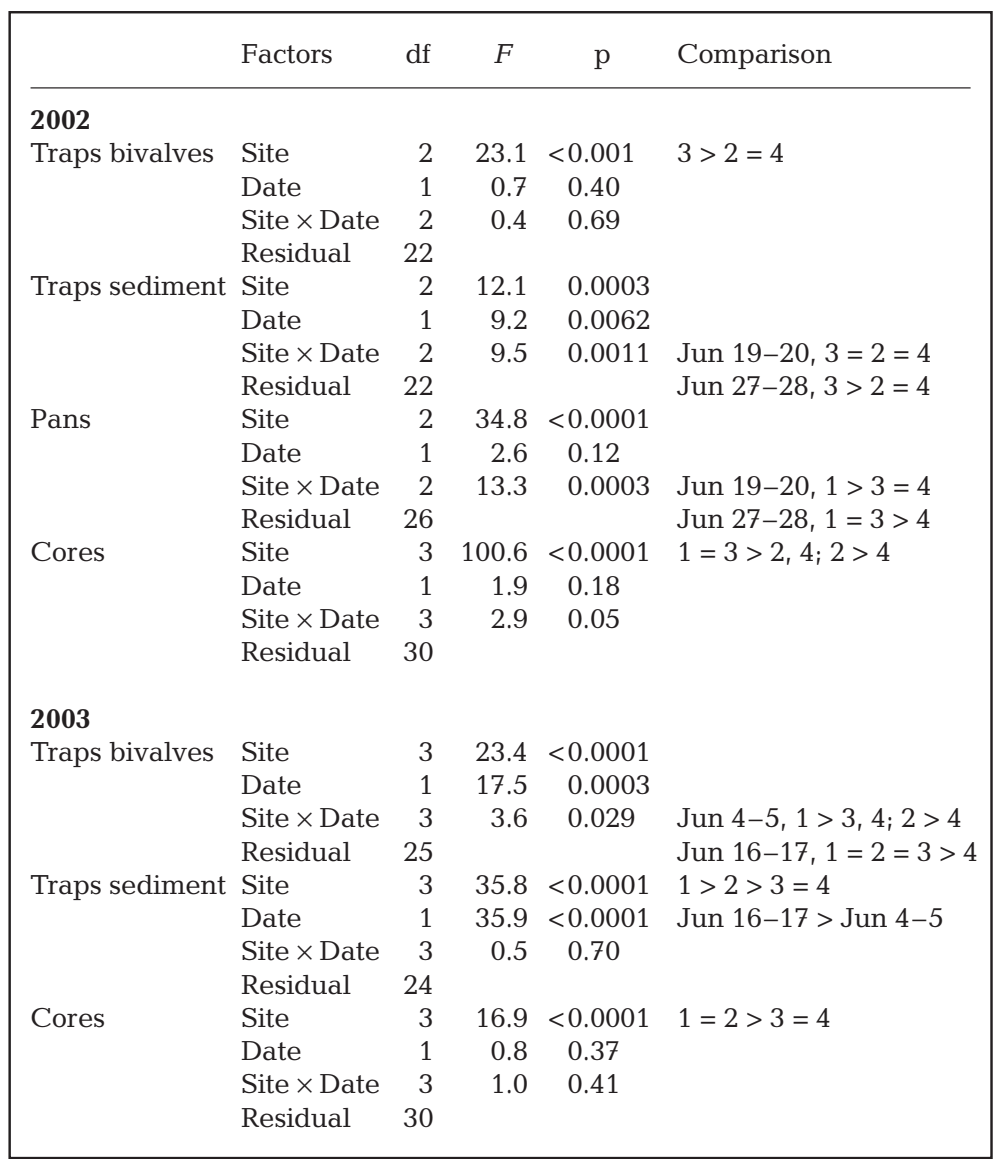

Per capita (relative) dispersal rates (Fig. 6) were calculated for each site as the rate of transport of bivalves into the traps divided by the ambient density. Transport rates into traps in $24 \mathrm{~h}$ ranged from 0.12 (Site 2, June 20) to 24 (Site 1, June 28) times ambient density in 2002 and, with the exception of Sites 3 and 4 on June 5 when no bivalves were detected in traps, 1.14 (Site 2, June 5) to 14 (Site 1, June 17) times ambient density in 2003 (Fig. 6), indicating rapid turnover of juveniles in both years.

To examine whether spatial and temporal patterns of dispersal of juvenile bivalves were more strongly linked to sediment transport or to supply of juveniles, multiple regression was used to examine both the relationship between the transport rate of bivalves into traps, the weight of sediment in traps, and ambient density of bivalves in the cores and the relationship between the transport rate of bivalves into pans and 


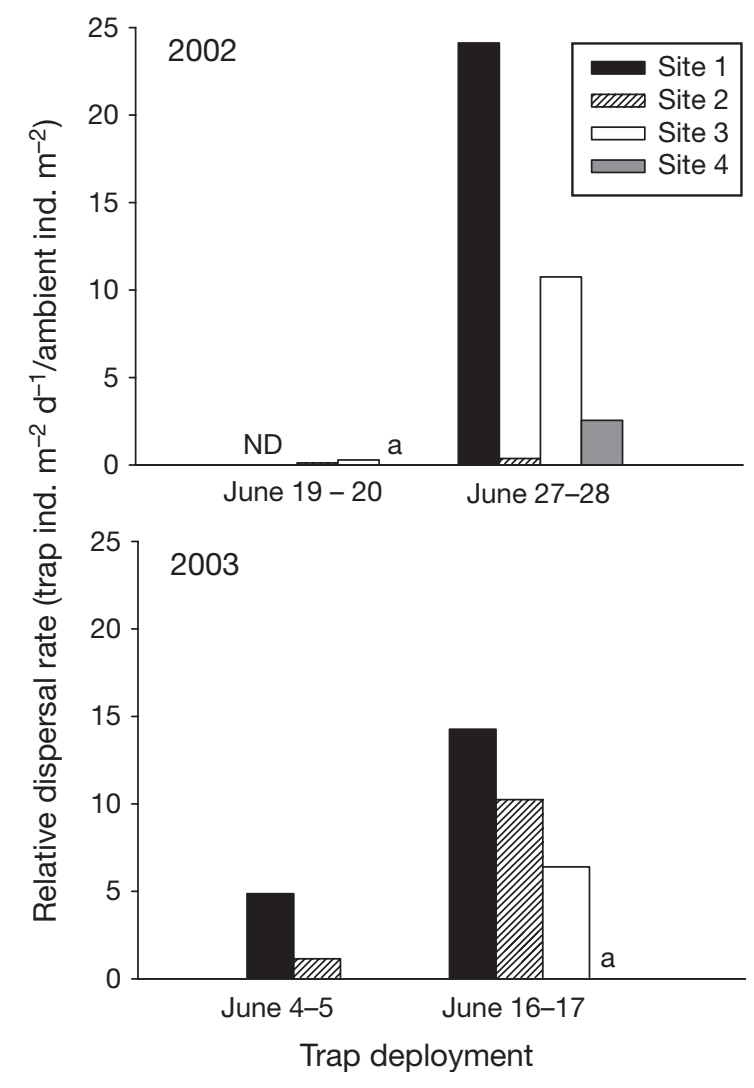

Fig. 6. Relative dispersal rates of bivalves into traps on June 19-20 and 27-28, 2002 and June 4-5 and 16-17, 2003. Relative dispersal rates calculated as a ratio: transport of bivalves into traps: ambient density of bivalves (from cores) at a site. No usable data (ND) obtained from Site 1 traps on June 20, 2002 since they were deployed projecting above the bottom. $\mathrm{a}=$ sites/dates for which relative dispersal could not be calculated, because no bivalves were found in the cores

the same factors (means for each site and date; no data for Site 1 on June 20, 2002). Transport rates of bivalves into traps in 2002 and 2003 were significantly related to the weight of sediment in traps (bivalves in traps, Fig. 7), but not to bivalve density in cores (Table 6). For rates of dispersal into pans in 2002 (Site 2 not included), the regression model was significant, although neither sediment weight nor bivalve density in cores was individually significant (Table 6). Density of bivalves in cores and weight of sediment in traps were uncorrelated $(\mathrm{r}=-0.06)$ in 2002 but correlated in 2003 ( $\mathrm{r}=0.85)$.

We hypothesized that patterns of sediment transport and bivalve transport into traps were driven by variation in current speed. Regression was used to examine the relationship between mean bivalve or sediment transport at the sites (Site 1, June 20 excluded) and mean velocity (absolute value of velocity $50 \mathrm{~cm}$ above bottom, or estimated shear velocity). Weight of sedi-

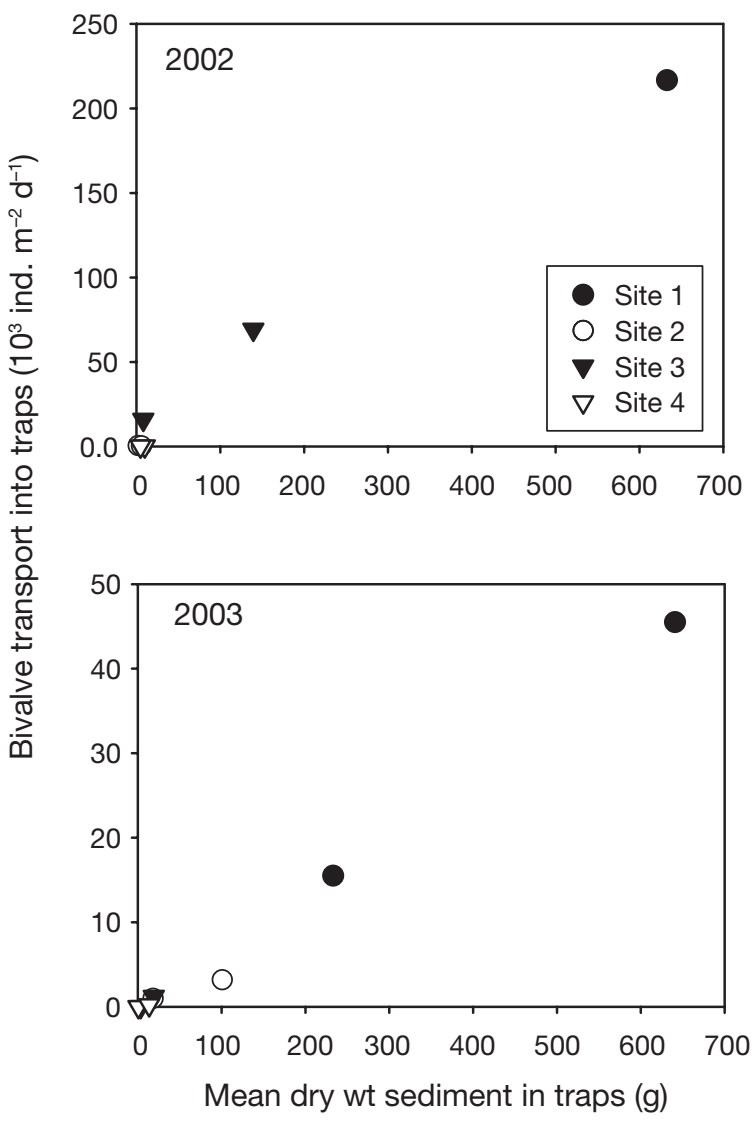

Fig. 7. Relationship between mean transport of bivalves into bedload traps and mean dry weight of sediment in traps for each site and date in 2002 and 2003

ment in traps and bivalve transport into traps were both significantly related to mean velocity at $50 \mathrm{~cm}$ above the bottom and to mean shear velocity (Table 6). In 2003, the relationship between sediment and bivalve transport with mean shear velocity was less strong because of the relatively variable estimates of Reynolds stress.

Large cores (diameter $12 \mathrm{~cm}$, depth $17 \mathrm{~cm}$ ) were collected in June 2003 to assess the abundance of larger juvenile (>2 mm) and adult bivalves other than Gemma gemma (which would have passed through the sieve) at the study sites. Only Mercenaria mercenaria, Tellina agilis, and Mytilus spp. $>2 \mathrm{~mm}$ were found in the large cores. Maximum size of $T$. agilis and juvenile $M$. mercenaria were comparable to those collected in the traps, pans, and shallow cores: $9.6 \mathrm{~mm}$ and $13.9 \mathrm{~mm}$ SL respectively. Two adult $M$. mercenaria individuals $>75 \mathrm{~mm}$ SL were also collected in the large cores. Because G. gemma passed through the sieve, the density of bivalves $>2 \mathrm{~mm}$ differed in their pattern from those collected in the small cores in that they were most abundant at Site 2, and second 
Table 6. Regression analysis of mean rates of bivalve transport into traps and pans (2002 only) and sediment weight in traps (2002 and 2003). Independent variables were mean weight of sediment in traps and ambient density of bivalves in cores (for bivalves in traps and pans), mean velocity $50 \mathrm{~cm}$ above bottom, and shear velocity. Data were means for each combination of site and date. $n=7$ (2002: no data for traps at Site 1 on June 20) or $n=8$ (2003)

\begin{tabular}{|c|c|c|c|c|c|}
\hline & Source & df & $F$ & $\mathrm{p}$ & $\mathrm{r}^{2}$ \\
\hline \multicolumn{6}{|l|}{2002} \\
\hline \multirow[t]{4}{*}{ Trap bivalves } & Model & 2 & 189.77 & 0.0001 & 0.99 \\
\hline & Weight of sediment in traps & 1 & 380 & $<0.0001$ & \\
\hline & Ambient density in cores & 1 & 1.3 & 0.32 & \\
\hline & Error & 4 & & & \\
\hline \multirow[t]{4}{*}{ Pan bivalves } & Model & 2 & 28.8 & 0.03 & 0.97 \\
\hline & Weight of sediment in traps & 1 & 3.1 & 0.22 & \\
\hline & Ambient density in cores & 1 & 6.8 & 0.12 & \\
\hline & Error & 2 & & & \\
\hline \multirow[t]{4}{*}{ Trap sediment } & Velocity $50 \mathrm{~cm}$ above bottom & 1 & 18.2 & 0.008 & 0.785 \\
\hline & Error & 5 & & & \\
\hline & Shear velocity & 1 & 19.1 & 0.007 & 0.792 \\
\hline & Error & 5 & & & \\
\hline \multirow[t]{4}{*}{ Trap bivalves } & Velocity $50 \mathrm{~cm}$ above bottom & 1 & 13.8 & 0.013 & 0.734 \\
\hline & Error & 5 & & & \\
\hline & Shear velocity & 1 & 21.2 & 0.006 & 0.809 \\
\hline & Error & 5 & & & \\
\hline \multicolumn{6}{|l|}{2003} \\
\hline \multirow[t]{4}{*}{ Trap bivalves } & Model & 2 & 367.4 & $<0.0001$ & 0.99 \\
\hline & Weight of sediment in traps & 1 & 202.1 & $<0.0001$ & \\
\hline & Ambient density in cores & 1 & 0.05 & 0.83 & \\
\hline & Error & 5 & & & \\
\hline \multirow[t]{4}{*}{ Trap sediment } & Velocity $50 \mathrm{~cm}$ above bottom & 1 & 24.9 & 0.003 & 0.806 \\
\hline & Error & 6 & & & \\
\hline & Shear velocity & 1 & 4.95 & 0.07 & 0.452 \\
\hline & Error & 6 & & & \\
\hline \multirow[t]{4}{*}{ Trap bivalves } & Velocity $50 \mathrm{~cm}$ above bottom & 1 & 32.2 & 0.001 & 0.843 \\
\hline & Error & 6 & 5.71 & 0.05 & 0.488 \\
\hline & Shear velocity & 1 & & & \\
\hline & Error & 6 & & & \\
\hline
\end{tabular}

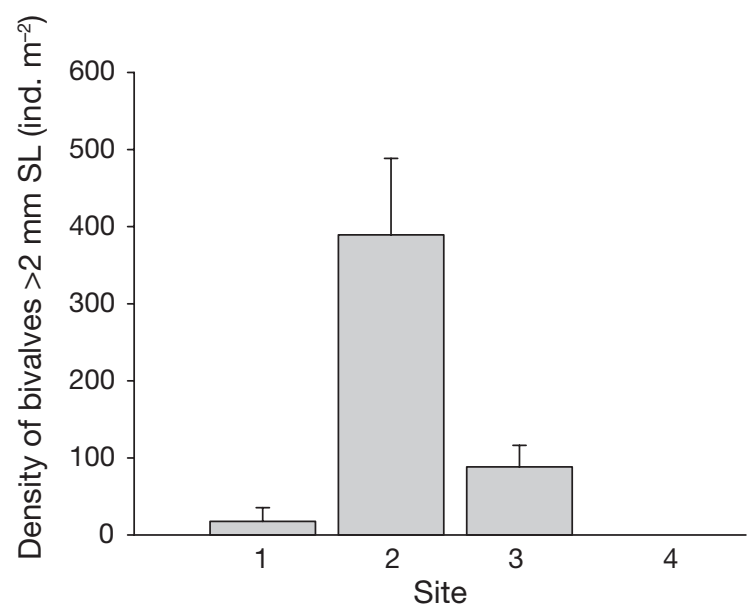

Fig. 8. Mean (+SE, $\mathrm{n}=5$ for each site) abundance of bivalves $>2 \mathrm{~mm}$ in size collected in large cores (depth $17 \mathrm{~cm}$ ) at the 4 Navesink estuary sites on June 17, 2003. SL = shell length most abundant at Site 3 (Fig. 8). The abundance of bivalves $>2 \mathrm{~mm}$ was significantly greater at Site 2 than at Site 1, and did not differ from that at Site $3\left(F_{2,12}\right.$ = 9.92, $\mathrm{p}=0.003$; Tukey-Kramer HSD $\mathrm{p}<$ 0.05). Site 4 was not included in the analysis as no bivalves of this size were detected at this site.

\section{Ebb versus flood tide}

Because the Navesink estuary is floodtide dominated, we predicted that bivalve and sediment transport would occur primarily during flood tides. Rates of transport were compared between ebb and flood tide on June 11 and 18, 2003 (Fig. 9). As in the $24 \mathrm{~h}$ samples, a significantly greater weight of sediment was collected in traps at Site 1 than at Site 3 on both flood and ebb tides (Table 7). At Site 1 , significantly more sediment was collected on flood than ebb tides, while at Site 3, transport of sediment was more balanced between the 2 phases of the tidal cycle, with no difference between tidal states (Table 7). Because only 1 bivalve was collected during these $6 \mathrm{~h}$ intervals at Site 3, ANOVA of transport rate of bivalves was carried out for Site 1 only. Similar to the results for sediment in traps, the transport rate of bivalves at Site 1 was significantly greater during flood than ebb tide $\left(F_{1,8}=6.32, \mathrm{p}=0.04\right)$ and did not differ significantly between June 11 and $18\left(F_{1,8}=1.83, \mathrm{p}=0.22\right)$; there was no significant interaction between Site and Date $\left(F_{1,8}=1.15, \mathrm{p}=0.31\right)$.

Table 7. Three-way ANOVA of dry weight of sediment in traps during ebb/flood sampling at Sites 1 and 3 in 2003. Fixed factors were Site (1 and 3), Date (June 11 and 18), and Tidal state (ebb and flood). $\mathrm{n}=3$ to 5 replicates

\begin{tabular}{|lccc|}
\hline Source & df & $F$ & $p$ \\
\hline Date & 1 & 0.02 & 0.89 \\
Site & 1 & 82.4 & $<0.0001$ \\
Tidal state & 1 & 20.9 & 0.0002 \\
Date $\times$ Site & 1 & 1.3 & 0.27 \\
Site $\times$ Tidal state & 1 & 20.2 & 0.0002 \\
Date $\times$ Tidal state & 1 & 0.9 & 0.36 \\
Date $\times$ Site $\times$ Tidal state & 1 & 0.03 & 0.87 \\
Error & 22 & & \\
\hline
\end{tabular}



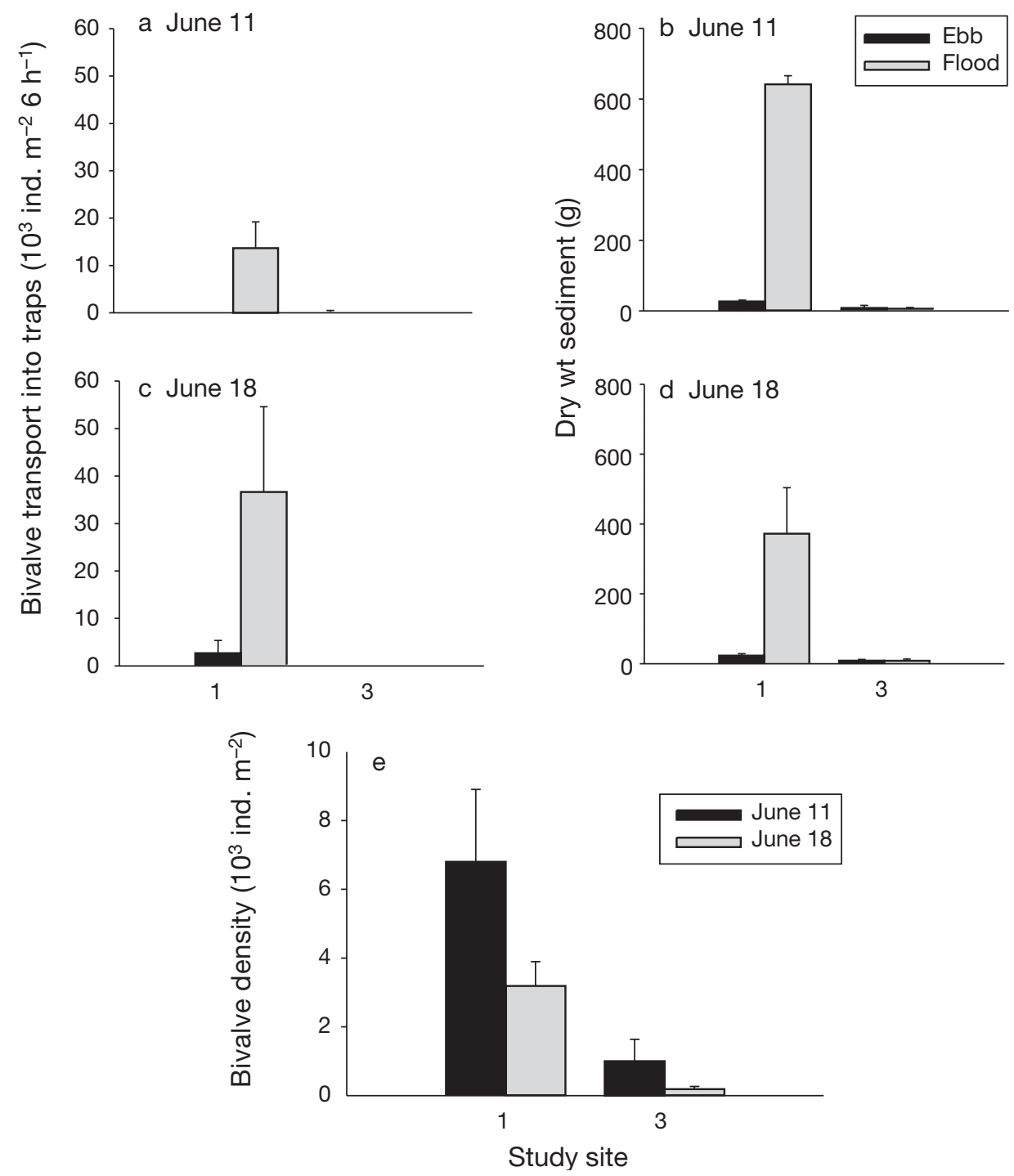

Fig. 9. (a, c) Mean (+SE, n = 2-5 for each site) transport of bivalves into bedload traps. (b, d) Dry weight of sediment collected in traps. (e) Bivalve density in the surrounding sediment, at Navesink estuary Sites 1 and 3 during flood and ebb tide on June 11 and 18,2003

\section{DISCUSSION}

Rates of dispersal of juvenile bivalves in the Navesink estuary were very high, particularly at Site 1. Daily rates of transport often exceeded the ambient density of bivalves, suggesting that turnover of juvenile bivalves occurs constantly in this system. High rates of dispersal of juvenile bivalves have also been observed in other systems. Turnover of bivalves has been estimated to occur within one to several days in a number of soft bottom habitats (Armonies 1994, Commito et al. 1995a, Norkko et al. 2001). Rapid turnover also has been observed for other groups of macrofauna and meiofauna on tidal flats (e.g. Commito \& Tita 2002, Commito et al. 2005). Bivalves collected in the traps and pans were representative of those observed in the ambient area, consisting of juveniles of a variety of species and juveniles and Gemma gemma adults. In general, sizes of juvenile and G. gemma adult bivalves were similar between the ambient area (those collected in cores) and traps. Commito et al. (1995a) also found a size correspondence for G. gemma between traps and ambient clams. In 2002, the proportion of recently settled bivalves $(<500 \mu \mathrm{m})$ was smaller in pans than in traps or cores. Also, on June 28, 2002 the size distribution of G. gemma differed between traps, pans, and cores at Site 3. The presence of larger juveniles in pans may be due to size differences in behaviour that lead larger juveniles to colonize and/or remain in pans. Larger juvenile bivalves are less vul- 
nerable to erosion and resuspension than individuals $<500 \mu \mathrm{m}$. Hunt \& Mullineaux (2002) also found size differences between traps, pans, and ambient cores. However, in that case, Mya arenaria individuals $>2 \mathrm{~mm}$ were found in traps on spring tides and in ambient cores, but not in pans. The size difference between pans and cores in the present study may be due in part to the presence of a small number of bivalves in the sediment in the pans at the start of the deployment.

Bedload traps provided information on total flux of material passing a specific point on the sediment surface, while pans measured the net flux of bivalves. Spatial patterns of transport into pans were similar to those into traps, suggesting that variation between sites was due more to differences in supply of colonists than to differences in the colonization rate of individuals that arrive at a particular site. Densities were 1 to 2 orders of magnitude lower in pans than traps, which was not surprising, as most of the individuals moving past a location in the bedload or in suspension would likely have continued to disperse had they not been collected in a trap, while other individuals would be resuspended after colonizing a pan. Similarly, Hunt and Mullineaux (2002) found order of magnitude differences in densities of Mya arenaria between traps and pans on an intertidal flat in Massachusetts, USA. In contrast, densities of bivalves collected on an intertidal sandflat in New Zealand by Turner et al. (1997) were similar between pans and traps. Differences between studies in gross versus net flux of individuals may be due to a variety of factors, including effects of hydrodynamics on colonization and resuspension and differences in behaviour between species.

Our results show that strong spatial variability in rates of transport of bivalves within the Navesink estuary is related to spatial variation in sediment transport and current velocities. Bivalve transport rates into traps and pans were strongly related to rates of sediment transport. This suggests that dispersal of these species of juvenile bivalves (of which Gemma gemma are the most abundant) is primarily initiated by sediment erosion and occurs as bedload transport. Other studies also have found strong relationships between sediment transport and bivalve transport in the field (Emerson \& Grant 1991, Commito et al. 1995a, b, Hunt \& Mullineaux 2002) and the laboratory (Hunt 2005). This type of relationship occurs in other groups of macrofauna (e.g. Commito et al. 2005, Lundquist et al. 2006). In contrast, in species where thread-drifting or crawling is common, juvenile dispersal can occur at speeds below the threshold for sediment erosion (e.g. Lundquist et al. 2004). As a result, field measurements of rates of dispersal of some bivalves may be uncoupled from sediment transport (e.g. Norkko et al. 2001).
In the present study, measurements of current speed and estimates of shear velocities were made synoptically with measurements of transport rates of bivalves and sediment. The characterization of hydrodynamics was more detailed than in previous studies of postlarval dispersal (but see Lundquist et al. 2006), allowing a good assessment of the relationship between current speed and bivalve and sediment dispersal. Bivalve transport and sediment transport were related to current speed at $50 \mathrm{~cm}$ above bottom and to estimated shear velocity. Recent work on sandflats in New Zealand, where waves are particularly important in sediment and organism transport, found that dispersal of macrofauna into traps was related to maximum wave height, bedload velocities and optical back-scatter (OBS) data (Lundquist et al. 2006). Previous studies have examined the relationship between wind speed and direction and bivalve dispersal (e.g. Commito et al. 1995b). However, wind data are not always a good proxy for hydrodynamic conditions, particularly in systems like the Navesink estuary where flow is primarily tidally-driven because of the small fetch.

In 2003, sediment and bivalve transport were more strongly related to current velocity at $50 \mathrm{~cm}$ above the bottom than to estimated shear velocity. This was not unexpected because shear velocity is a measure of friction on the bottom and should be a better predictor of sediment and clam erosion than velocity above the bottom. This result is likely due to the greater amount of noise in the Reynolds stress estimates, particularly those from the ADCPs, than in the current speeds above bottom. In 2002, most sites had shear velocity estimates from quadratic stresses - simply a function of velocity $50 \mathrm{~cm}$ above bottom and a drag coefficient - so both velocity above bottom and shear velocity have similar patterns. In this study, juvenile bivalve dispersal is more closely related to sediment transport than velocity. This result is likely due to the effects of other factors such as sediment erodability on sediment transport, and consequently, on bivalve transport. Sediment erodability and transport of organisms are influenced by the effects of biogenic structures, such as mussel beds (e.g. Commito et al. 2005). Rates of transport were low at Sites 2 and 4, where the sediment was covered with tubes created by the amphipod Ampelisca abdita. In the laboratory, Hunt (2005) found that erosion of juvenile Mya arenaria and sediment collected from the 4 sites used in the present study varied strongly among sites at a common shear velocity, likely due to an effect of the amphipod mats on sediment erosion. Mats created by this amphipod may impact bivalves significantly. MacKenzie et al. (2006) suggested that dense A. abdita tube mats may enhance abundance of Mercenaria mercenaria in nearby Raritan Bay, New Jersey, USA by offering protection from predators. 
Differences in bivalve dispersal among sites could also be driven by spatial variation in juvenile bivalve availability. Sites with greater transport of juvenile bivalves generally had both higher sediment transport and greater densities of juvenile bivalves. However, regressions indicated that means of bivalve transport rates into traps at the sites were much more strongly related to weight of sediment in traps than to local bivalve density (cores). This suggests that sediment transport is more important than local density in driving between-site and within-year variation in juvenile dispersal. In contrast, Hunt \& Mullineaux (2002) found that the flux of Mya arenaria into bedload traps was related to both sediment weight and ambient density. Rates of dispersal in the present study may be more strongly related to the supply of juveniles over a broader spatial scale. For example, Commito et al. (1995b) found that sediment flux and abundance in other traps was often a good predictor of number of individuals in traps for various species of macrofauna, but that abundance in the adjacent ambient sediment generally was not.

Differences in rates of bivalve transport among dates were not as obvious as those among sites. The greater number of differences among dates in 2003 than in 2002 is likely due to the fact that there was a greater difference in velocities between the 2 dates sampled in 2003 than in 2002. Differences in current velocity between sampling dates were not the maximum possible in either year. However, regardless of sampling date, the magnitude of variation of maximum current speeds within a site over a spring/neap cycle was considerably less than the differences among sites on a given date (Fig. 2). Therefore, it is expected that, even for extreme tides, differences among sites would remain greater than those among dates.

Rates of transport of bivalves and sediment were compared on ebb and flood tides at Sites 1 and 3. We hypothesized that transport would occur primarily on flood tides due to the flood-domination of tidal currents in the Navesink estuary. Differences in shear velocity between ebb and flood tide were not as marked at Site 3 as they were at Site 1. At Site 1, sediment and bivalve transport occurred primarily during flood tide, while the amount of material transported into traps at Site 3 was similar on flood and ebb tides. As a result, sediment and bivalves at Site 1 are likely to be transported further into the estuary until they reach an area where current velocities are lower. In contrast, at Site 3, bivalves may be transported back and forth with less net distance of dispersal into the estuary. Flood or ebb domination of tidal currents and variation in the strength of this phenomenon within an estuary may have important consequences for the scale of dispersal of juvenile invertebrates. The gradi- ent in transport in flood-dominated estuaries, such as that observed in the Navesink estuary, may result in a strong trapping mechanism for juvenile (and larval) invertebrates. Chant \& Stoner (2001) previously demonstrated that the hydrodynamic characteristics of the Navesink estuary resulted in trapping suspended sediment particles.

Laboratory experiments with sediments from the Navesink estuary (Hunt 2005) suggested that dispersal of juvenile bivalves in the field would be linked to sediment transport and that dispersal would be considerably greater at Sites 1 and 3 than at Sites 2 and 4 . This field study confirms this hypothesis, with the exception of low bivalve dispersal at Site 3 in 2003, likely due to lower rates of sediment transport at this site in that year but possibly also to low ambient densities of bivalves. The results suggest that variability in hydrodynamic conditions is the primary factor driving the strong spatial variability in bivalve dispersal observed in the field. Rates of dispersal of juvenile bivalves in the Navesink estuary were very high, indicating that in this estuary, similar to many other systems, juvenile dispersal is likely to have important consequences for patterns of bivalve recruitment. The strong relationship between bivalve dispersal and sediment transport and velocity suggests that dispersal of these species is passively initiated by sediment transport. Under these conditions, knowledge of sediment transport and hydrodynamic conditions in an estuary can be used to predict juvenile bivalve dispersal. A particle trajectory model of juvenile bivalve dispersal within the Navesink estuary is currently under development (authors' unpubl. data).

Acknowledgements. L. Jennings and K. Saur assisted in collecting and preserving the biological samples and C. Haldeman and E. Hunter assisted with the hydrodynamic data. B. Fullerton and J. Turner captained the Stevens Institute of Technology's RV 'Phoenix'. J. Dobarro, D. Andrews, B. Dixon, and D. Crowell carried out some of the SCUBA diving. S. Fries carried out the 2003 sediment analysis for Sites 1 and 3. We are grateful to K. Rankin of Stevens Institute of Technology for the loan of an ADV and P. Francis and J. Francis for the use of their dock for the duration of the study. The Fairhaven marina allowed use of their facility and equipment in the recovery of the current meter moorings. This research was funded by a grant from the National Science Foundation USA's Biological Oceanography program (grant \# 0136916) to H.L.H. and R.J.C. This is Contribution 2007-13 from the Institute of Marine and Coastal Sciences at Rutgers University.

\section{LITERATURE CITED}

Armonies W (1992) Migratory rhythms of drifting juvenile molluscs in tidal waters of the Wadden Sea. Mar Ecol Prog Ser 83:197-206

Armonies W (1994) Turnover of postlarval bivalves in sediments of tidal flats in Königshafen (German Wadden Sea). Helgol Meeresunters 48:291-297 
Armonies W (1996) Changes in distribution patterns of 0group bivalves in the Wadden Sea: byssus-drifting releases juveniles from the constraints of hydrography. J Sea Res 35:232-334

Beukema JJ, de Vlas J (1989) Tidal-current transport of thread-drifting postlarval juveniles of the bivalve Macoma balthica from the Wadden Sea to the North Sea. Mar Ecol Prog Ser 52:193-200

Bouma H, Vries PPD, Duiker JMC, Herman PMJ, Wolff WJ (2001) Migration of the bivalve Macoma balthica on a highly dynamic tidal flat in the Westerschelde estuary, The Netherlands. Mar Ecol Prog Ser 224:157-170

Chant RJ, Stoner AW (2001) Particle trapping in a stratified flood-dominated estuary. J Mar Res 59:29-51

Commito JA, Tita G (2002) Differential dispersal rates in an intertidal meiofaunal assemblage. J Exp Mar Biol Ecol 268:237-256

Commito JA, Currier CA, Kane LR, Reinsel KA, Ulm IM (1995a) Dispersal dynamics of the bivalve Gemma gemma in a patchy environment. Ecol Monogr 65:1-20

Commito JA, Thrush SF, Pridmore RD, Hewitt JE, Cummings VJ (1995b) Dispersal dynamics in a wind-driven benthic system. Limnol Oceanogr 40:1513-1518

Commito JA, Celano EA, Celico HJ, Como S, Johnson CP (2005) Mussels matter: postlarval dispersal dynamics altered by a spacially complex ecosystem engineer. J Exp Mar Biol Ecol 316:133-147

Cummings VJ, Pridmore RD, Thrush SF, Hewitt JE (1993) Emergence and floating behaviour of post-settlement juveniles of Macomona liliana (Bivalvia: Tellinacea). Mar Behav Physiol 24:25-32

Cummings VJ, Pridmore RD, Thrush SF, Hewitt JE (1995) Post-settlement movement by intertidal benthic macroinvertebrates: Do common New Zealand species drift in the water column? NZ J Mar Freshw Res 29:59-67

Dunn R, Mullineaux LS, Mills SW (1999) Resuspension of postlarval soft-shell clams Mya arenaria through disturbance by the mud snail Ilyanassa obsoleta. Mar Ecol Prog Ser 180:223-232

Emerson CW (1991) A method for the measurement of bedload sediment transport and passive faunal transport on intertidal sandflats. Estuaries 14:361-371

Emerson CW, Grant J (1991) The control of soft-shell clam (Mya arenaria) recruitment on intertidal sandflats by bedload sediment transport. Limnol Oceanogr 36: $1288-1300$

Folk RL (1965) Petrology of sedimentary rocks. Hemphill, Austin, TX

Fugate DA, Chant RJ (2005) Near-bottom shear stresses in a small highly-stratified estuary. J Geophys Res C03022:doi: 10.1029/2004JC002563

Gulmann LK, Mullineaux LS, Hunt HL (2001) Effects of caging on transport of postlarval soft-shell clams (Mya arenaria). J Shellfish Res 20:135-142

Hewitt JE, Cummings VJ, Ellis JI, Funnell G, Norkko A, Talley TS, Thrush SF (2003) The role of waves in the colonisation of terrestrial sediments deposited in the marine environment. J Exp Mar Biol Ecol 290:19-47

Editorial responsibility: Erik Bonsdorff (Contributing Editor), Turku, Åbo, Finland
Hiddink JG (2003) Modelling the adaptive value of intertidal migration and nursery use in the bivalve Macoma balthica. Mar Ecol Prog Ser 252:173-185

Hunt HL (2004) Transport of juvenile clams: effects of clam species and sediment grain size. J Exp Mar Biol Ecol 312: 271-284

Hunt HL (2005) Effects of sediment source and flow regime on clam and sediment transport. Mar Ecol Prog Ser 296: 143-153

Hunt HL, Mullineaux LS (2002) The roles of predation and postlarval transport in recruitment of the soft shell clam Mya arenaria. Limnol Oceanogr 47:151-164

Lundquist CJ, Pilditch CA, Cummings VJ (2004) Behaviour controls post-settlement dispersal by the juvenile bivalves Austrovenus stutchburyi and Macomona liliana. J Exp Mar Biol Ecol 306:51-74

Lundquist CJ, Thrush SF, Hewitt JE, Halliday J, MacDonald I, Cummings VJ (2006) Spatial variability in recolonisation potential: influence of organism behaviour and hydrodynamics on the distribution of macrofaunal colonists. Mar Ecol Prog Ser 324:67-81

MacKenzie Jr CL, Pikanowski R, McMillan DG (2006) Ampelisca amphipod tubes may enhance abundance of northern quahogs Mercenaria mercenaria in muddy sediments. J Shellfish Res 25:841-847

Miller MC, McCave IN, Komar PD (1977) Threshold of sediment motion under unidirectional currents. Sedimentology 24:507-527

Norkko A, Cummings VJ, Thrush SF, Hewitt JE, Hume T (2001) Local dispersal of juvenile bivalves: implications for sandflat ecology. Mar Ecol Prog Ser 212:131-144

Olivier F, Vallet C, Dauvin JC, Retière C (1996) Drifting in post-larvae and juveniles in an Abra alba (Wood) community of the eastern part of the Bay of Seine (English Channel). J Exp Mar Biol Ecol 199:89-109

Roegner C, Andre C, Lindegarth M, Eckman JE, Grant J (1995) Transport of recently settled soft-shell clams (Mya arenaria L.) in laboratory flume flow. J Exp Mar Biol Ecol 187:13-26

Sigurdsson JB, Titman CW, Davies PA (1976) The dispersal of young post-larval bivalve molluscs by byssus threads. Nature 262:386-387

Thomas MLH (1973) Introducing the sea. Huntsman Marine Science Centre, St. Andrews, NB

Thrush SF, Whitlatch RB, Pridmore RD, Hewitt JE, Cummings VJ, Wilkinson MR (1996) Scale-dependent recolonization: the role of sediment stability in a dynamic sandflat habitat. Ecology 77:2472-2487

Turner SJ, Grant J, Pridmore RD, Hewitt JE, Wilkinson MR, Hume TM, Morrisey DJ (1997) Bedload and water-column transport and colonization processes by post-settlement benthic macrofauna: does infaunal density matter? J Exp Mar Biol Ecol 216:51-75

Vogel S (1994) Life in moving fluids: the physical biology of flow. Princeton University Press, Princeton, NJ

Zajac RN, Whitlatch RB (2003) Community and populationlevel responses to disturbance in a sandflat community. J Exp Mar Biol Ecol 294:101-125

Submitted: November 21, 2005; Accepted: June 5, 2007 Proofs received from author(s): November 12, 2007 